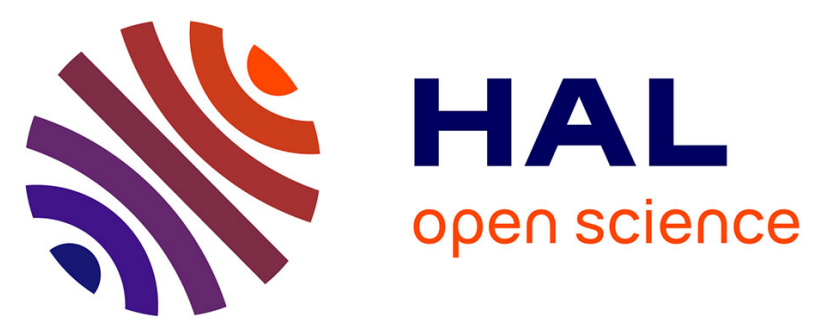

\title{
Removal of emerging micropollutants from wastewater by activated carbon adsorption: Experimental study of different activated carbons and factors influencing the adsorption of micropollutants in wastewater
}

R. Mailler, J. Gasperi, Y. Coquet, C. Derome, A. Buleté, E. Vulliet, Adèle

Bressy, G. Varrault, G. Chebbo, V. Rocher

\section{To cite this version:}

R. Mailler, J. Gasperi, Y. Coquet, C. Derome, A. Buleté, et al.. Removal of emerging micropollutants from wastewater by activated carbon adsorption: Experimental study of different activated carbons and factors influencing the adsorption of micropollutants in wastewater. Journal of Environmental Chemical Engineering, 2016, 4 (1), 10.1016/j.jece.2016.01.018 . hal-01266245

HAL Id: hal-01266245

https://hal-enpc.archives-ouvertes.fr/hal-01266245

Submitted on 19 Jun 2018

HAL is a multi-disciplinary open access archive for the deposit and dissemination of scientific research documents, whether they are published or not. The documents may come from teaching and research institutions in France or abroad, or from public or private research centers.
L'archive ouverte pluridisciplinaire HAL, est destinée au dépôt et à la diffusion de documents scientifiques de niveau recherche, publiés ou non, émanant des établissements d'enseignement et de recherche français ou étrangers, des laboratoires publics ou privés. 
Removal of emerging micropollutants from wastewater by activated carbon adsorption: experimental study of different activated carbons and factors influencing the adsorption of micropollutants in wastewater

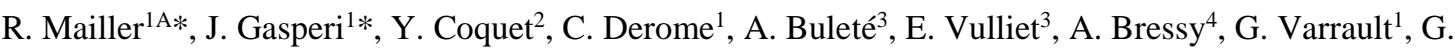
Chebbo $^{4}$ and V. Rocher ${ }^{5}$

${ }^{1}$ LEESU (UMR MA 102, Université Paris-Est, AgroParisTech), Université Paris-Est Créteil, 61 avenue du Général de Gaulle, 94010 Créteil Cedex, France. (E-mail: maillerr@leesu.enpc.fr; gasperi@u-pec.fr) ${ }^{2}$ SAUR, Direction de la Recherche et du Développement, 1 rue Antoine Lavoisier, 78064 Guyancourt, France.

${ }^{3}$ Université de Lyon, Institut des Sciences Analytiques, UMR5280 CNRS, Université Lyon 1, ENS-Lyon, 5 rue de la Doua, 69100 Villeurbanne, France.

${ }^{4}$ LEESU (UMR MA 102, Université Paris-Est, AgroParisTech), École des Ponts ParisTech, 6-8 avenue Blaise Pascal, Champs-sur-Marne, 77455 Marne-la-Vallée Cedex 2, France.

${ }^{5}$ SIAAP, Direction du Développement et de la Prospective, 82 avenue Kléber, 92700 Colombes, France.

* Corresponding authors

\section{HIGHLIGHTS}

- BET surface and bulk density of activated carbons are correlated to micropollutants adsorption,

- The activated carbon dose and the contact time have a great influence on adsorption,

- $\mathrm{FeCl}_{3}$ has a positive influence on micropollutants adsorption by activated carbon $(+10-15 \%)$,

- Both the quantity and composition of organic matter impact the adsorption,

- UV-254 removals are correlated to several micropollutants removals.

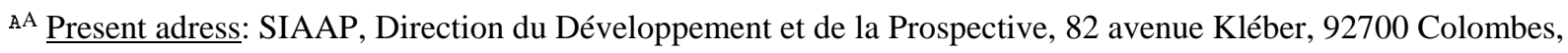
France. (Email: romain.mailler@siaap.fr) 


\section{ABSTRACT}

Activated carbon processes, initially designed for drinking water production, are tested for wastewater application in order to characterize their efficiency to remove micropollutants from wastewater treatment plants (WWTPs) discharges. In that purpose, a pilot was set up at the Seine Centre WWTP and is studied by the Paris sanitation service (SIAAP) and the Water Environment and Urban Systems laboratory (LEESU). The in-situ study raised several additional questions related to the structural and morphological properties of activated carbons, in order to select the proper material, the influence of operational parameters such as the activated carbon dose and the contact time, the role of organic matter concentration and composition, the presence of a residual concentration of methanol or the impact of ferric chloride addition. Thus, various complementary experiments were carried out at laboratory scale to improve the understanding of the micropollutants adsorption process on activated carbon, in particular on powdered activated carbon (PAC).

The results have highlighted a strong link between the efficiency of PACs and their specific surface (BET), which can be easily estimated by their bulk density. The study of the sorption process has also confirmed the strong influence of the PAC dose and the rapidity of the sorption kinetic. From an operational point of view, the ferric chloride injection seems to slightly improve most of the detected compounds adsorption, probably thanks to the coagulation of the dissolved organic matter colloidal fraction. In contrary, the presence in the water of a residual concentration of methanol seems to have no impact on the pharmaceuticals fate. The influence of the wastewater matrix where adsorption is performed is strong, with notably lower adsorption in settled water compared to various WWTP discharges. However, the dissolved organic carbon concentration is not always sufficient to explain sorption competitions in wastewater, and the composition and the distribution of the organic matter should be considered too. In particular, the carbon removal from biological treatments is the step that clearly modifies both the quantity and the composition of the organic matter. It has been observed that discharges from WWTPs operating with different biological processes (activated sludge, membrane bioreactor or biofiltration) have similar organic matter concentrations and compositions, and allows comparable removals of organic matter and micropollutants by adsorption. The lower performances on micropollutants observed in the settled water can be explained by the higher quantity of small protein-like molecules (fluorophores $\delta$ and $\gamma$ ), which compose the most competitive organic matter fraction for adsorption on activated carbon, compared to the other waters.

\section{KEYWORDS}


Adsorption; organic matter; pharmaceuticals; activated carbon; wastewater

\section{INTRODUCTION}

The presence of a large range of emerging micropollutants, particularly pharmaceuticals and hormones, personal care products or pesticides, has been highlighted in wastewater treatment plant (WWTP) discharges (Miège et al. 2009; Verlicchi et al. 2012; Loos et al. 2013; Mailler et al. 2015). Even if several hydrophobic, volatile or biodegradable compounds are strongly removed by conventional wastewater treatments (Ruel et al. 2012; Mailler et al. 2014b), most of micropollutants are not removed. Thus, various strategies of contamination reduction are assessed by the scientific community and water treatment engineers. Among them, the implementation of tertiary treatments dedicated to micropollutants elimination represents a relevant solution. In particular, adsorption on activated carbon appears to be efficient, very flexible and relatively cheap (Abegglen \& Siegrist 2012), together with not producing oxidation byproducts.

In this context, the Parisian public sanitation service (SIAAP) and the Water Environment and Urban Systems laboratory (LEESU) study, in collaboration with SAUR teams, the CarboPlus® process. This process is based on a fluidized bed of activated carbon (powder - PAC - or micro-grain - $\mu \mathrm{GAC}$ ) to remove micropollutants by adsorption. A large-scale pilot based on this technology was set up at the Seine Centre WWTP (240 $000 \mathrm{~m}^{3} /$ days $)$ to characterize the efficiency of activated carbon to remove a wide range of pollutants from WWTP discharges. The in-situ results are presented in (Mailler et al. 2015) for PAC.

In parallel to the in situ study, complementary laboratory scale experiments were conducted to i) better understand the relationships between activated carbon properties and the adsorption in wastewater and ii) to improve the understanding of the micropollutant adsorption mechanisms in wastewater application, in particular with PAC.

Activated carbon is characterized by different structural and morphological properties that can affect adsorption (Baudu et al. 2001; Li et al. 2002; Yu et al. 2008; Delgado et al. 2012). Thus, the first axis consists in studying the relationships between activated carbon properties and their efficiency to remove micropollutants. In particular, a focus is performed on the specific BET surface and the bulk density.

The second axis consists in studying the adsorption mechanism in wastewater representing a complex matrix. Indeed, the 
literature highlighted that the matrix where adsorption is performed plays a crucial role in the fate of molecules (Ebie $e t$ al. 2001; Ternes et al. 2002; de Ridder et al. 2010; de Ridder et al. 2011), particularly the organic matter which competes with pollutants for adsorption through direct sites competition or pore blocking. In addition, most of the studies were conducted for drinking water production or in surface waters, and the adsorption mechanisms were poorly assessed in wastewater. Thus, the influences of both the activated carbon dose and the contact time on the performances were assessed, as well as the influence of the organic matter and chemicals that can be injected within the process for operational purposes.

This article summarizes the results from the laboratory scale experiments conducted within this project. First, the relationships between micropollutants removals and activated carbon properties are assessed. Then, the influence of the dose of carbon, the contact time, the organic matter quantity and quality, the presence of a residual concentration of methanol and the injection of $\mathrm{FeCl}_{3}$ were studied.

\section{MATERIALS AND METHODS}

\section{Activated carbon characterization}

11 adsorbents, including micro and mesoporous PACs and $\mu \mathrm{GAC}$, have been selected based on their technical datasheets provided by the producers. Among them, 3 are commercialized by DaCarb® (PB 170®, PB 170-400® and PC 1000® France), 3 by Chemviron ${ }^{\circ}$ (WP 235®, Carbsorb 28® and Cyclecarb 305® - Belgium), 2 by Norit $($ W 35® and SA Super ${ }^{\circledR}$ - Netherlands) and 3 by Jacobi ${ }^{\circledR}($ LP $39 \circledR$, MP $25 \circledR$ and Hydro XP $17 \AA$ - Sweden). These activated carbons are recognized for their high organic pollutants affinity, but their use in wastewater was poorly studied in the literature.

Several structural properties such as the specific BET surface $\left(\mathrm{m}^{2} / \mathrm{g}\right)$, the porous volume $(\mathrm{mL} / \mathrm{g})$, the pore size distribution and the bulk density $\left(\mathrm{g} / \mathrm{cm}^{3}\right)$ have been measured on the 11 activated carbons. In addition, the particle size distribution and the micropollutant elimination have been determined for 4 of them: PB 170®, WP $235 \AA$, W $35 \AA$ and PC $1000 \AA$.

These structural properties have been analyzed at the University of Technology of Compiègne (UTC, France). The specific BET surface and the pore size distribution were measured with an ASAP 2010 Micromeritics analyzer equipped 
with a degasing station and a gas isotherm adsorption analyses station (nitrogen), according to the conventional methods used to determine these parameters. Fresh activated carbon samples $(100 \mathrm{mg})$ were degased at least $12 \mathrm{~h}$ before to be analyzed. Results correspond to the specific surface in $\mathrm{m}^{2} / \mathrm{g}$ obtained with the BET (Brunauer, Emett and Teller) method. The pore size distribution is determined with the BJH (Barrett, Joyner and Halenda) method, using the desorption curve of the same gas on the same analyzer. This method allows also calculating the microporous and mesoporous pore volumes. The bulk density was measured by weighting, with a high precision balance $(0.01 \mathrm{mg}), 50$ to $100 \mathrm{~mL}$ of activated carbon, measured with a $100 \mathrm{~mL}$ graduated cylinder. The activated carbon is introduced by small doses (10 mg) and is compacted every $10 \mathrm{~mL}$ to minimize the vacuum between particles.

The particles size distribution of the 4 PACs was measured with a Mastersizer 2000 Malvern laser particle sizer. Every analysis corresponds to 15000 light diffraction measures. 3 scans were performed at least per sample.

2. Pollutants and analytical procedures

For every sample, several parameters were measured in the dissolved phase: UV absorbance at 254 nm (UV-254), dissolved organic carbon (DOC) and concentrations of 16 pharmaceuticals and 2 pesticides (list and limit of quantification in supporting material - Table S1). Organic micropollutants were analyzed by the Institute of Analytical Sciences (ISA Villeurbanne, France), while UV-254 and DOC were measured by the SIAAP laboratory (French accreditation Colombes, France). Analytical protocols are validated and are given in (Mailler et al. 2015).

3D fluorescence spectrometry analyses were also performed by the LEESU. They allow generating a tridimensional matrix and to plot it on a 3D spectrum containing all excitation and emission spectra of the dissolved organic matter (DOM) present in a sample. This method gives the distribution of the different components of the DOM as they don't fluoresce in the same zones of the spectrum. The detailed description of 3D fluorescence spectrometry is given in (Hudson et al. 2007). Analyses have been performed with a Jasco FP-8300 spectrofluorometer equipped with a $1 \mathrm{~cm}$ quartz cell.

\section{Laboratory experiments protocols}

The laboratory experiments have been performed in the Seine Centre WWTP (Colombes, France) between April 2013 and May 2015. Wastewater was punctually sampled from the WWTP discharges with 10 L glass bottles, properly rinsed and grilled, and used the same day for experiments. Then, samples were filtered on glass fibers filters (GF/F $0.7 \mu \mathrm{m})$ after 
experiments, before to be sent to laboratories for analyses.

\subsection{Efficiency comparison of 4 PACs}

The efficiency of 4 PACs (PB 170®, WP 235®, W 35® and PC 1000® - Table 1) to remove micropollutants was assessed, by contacting individually $10 \mathrm{mg} / \mathrm{L}$ of each PAC with $1 \mathrm{~L}$ of Seine Centre WWTP (SEC) discharges during $45 \mathrm{~min}$ under strong mixing. After filtering, samples were conditioned and sent to ISA laboratory to analyze pharmaceuticals and pesticides.

\subsection{PAC dose and adsorption kinetic}

Regarding its performances, PB $170 ®$ was selected to characterize the relationship between PAC dose, contact time and micropollutant removal. First, $10 \mathrm{mg} / \mathrm{L}$ of this PAC were contacted with $1 \mathrm{~L}$ of SEC discharges under strong mixing during different contact times (5 - 10 - 30 - 45 - $60 \mathrm{~min}$ ), which are close from the pilot contact time range. Then, 3 PAC doses (5 - 10 - $20 \mathrm{mg} / \mathrm{L})$ were tested with $1 \mathrm{~L}$ of SEC discharges and during $45 \mathrm{~min}$.

\subsection{DOM and adsorption}

The DOM has been identified to play a crucial role in the adsorption process because it induces a competition with the organic micropollutants for adsorption (Matsui et al. 2003; de Ridder et al. 2011; Delgado et al. 2012). These phenomena have been principally observed with surface water and natural organic matter, but some recent studies also studied it in wastewater (Margot et al. 2013; Altmann et al. 2014). In this context, it is necessary to determine the role of both the quantity and the quality of the DOM in the adsorption process. To this end, 7 types of wastewater featuring by different levels of organic matter (Table 1) have been contacted under strong mixing with PAC (10 mg/L of PB $170 ®$ during- 45 min). Among the tested waters, 4 were WWTP discharges, from Seine Centre (SEC), Seine Aval (SAV), Seine Morée (SEM) and Seine Amont (SAM) WWTPs. The 3 other tested waters were outlet waters from the physico-chemical lamellar settling unit (SEC settled water) and the carbon biofiltration effluent (carbon removal) of SEC, as well as SEC settled water diluted with distilled water to reach a DOC level comparable to the WWTP discharges. The layouts of the different studied WWTPs are given in supporting material - Table S1, as well as the sampling points (red circles). The organic matter characteristics of these waters are different and given in Table 1. Among the 7 wastewaters, the 
micropollutants adsorption has been assessed with SEC settled water, SEC carbon biofiltration effluent, SEC and SAV discharges.

A 3D fluorescence spectrometry characterization has also been performed on these 7 waters, before and after contact with PAC. The spectra interpretation follows the fluorophores defined in (Parlanti et al. 2002), as indicated for SEC settled water and discharges in supporting material - Figure S2. $\alpha, \alpha^{\prime}$ and $\beta$ correspond to humic-like substances, $\gamma$ and $\delta$ respectively represents tyrosine-like and tryptophan-like proteins. Then, I1, I2, I3 and I4 indexes, respectively corresponding to the ratios $\alpha^{\prime} / \alpha, \beta / \alpha, \gamma / \alpha$ and $\delta / \alpha$, were calculated to evaluate the distribution. Finally, the humification index (HIX) and the biological activity index (BIX) were also evaluated (Zsolnay et al. 1999; Parlanti et al. 2002). The different fluorophores, HIX and BIX are given in Table 1 for the 7 tested wastewaters.

Table 1 - The 7 studied wastewaters and their main DOM characteristics

\begin{tabular}{|c|c|c|c|c|c|c|c|}
\hline & $\begin{array}{c}\text { SEC settled } \\
\text { water }\end{array}$ & $\begin{array}{c}\text { SEC settled } \\
\text { water } \\
\text { diluted }\end{array}$ & $\begin{array}{c}\text { SEC carbon } \\
\text { biofiltration } \\
\text { effluent }\end{array}$ & $\begin{array}{c}\text { SEC } \\
\text { discharges }\end{array}$ & $\begin{array}{c}\text { SAM } \\
\text { discharges }\end{array}$ & $\begin{array}{c}\text { SAV } \\
\text { discharges }\end{array}$ & $\begin{array}{c}\text { SEM } \\
\text { discharges }\end{array}$ \\
\hline $\begin{array}{c}\text { Biological } \\
\text { treatment }\end{array}$ & - & - & BF (C) & BF (C+N) & CAS (C+N) & $\begin{array}{c}\text { CAS (C) } \\
\text { BF (N) }\end{array}$ & $\begin{array}{c}\text { MBR } \\
\text { C+N }\end{array}$ \\
\hline $\begin{array}{c}\text { TOC } \\
(\mathrm{mgC/L})\end{array}$ & 32 & 7.8 & - & 7.3 & 7.2 & - & 5.5 \\
\hline $\begin{array}{c}\text { DOC } \\
(\mathrm{mgC/L})\end{array}$ & 27 & 7.7 & 6.6 & 6.8 & 6.6 & 11 & 5.2 \\
\hline $\begin{array}{c}\text { UV-254 } \\
(\mathrm{cm}-1)\end{array}$ & 0.859 & 0.203 & 0.120 & 0.150 & 0.173 & 0.237 & 0.140 \\
\hline Fluo $\alpha(\mathrm{UA})$ & 1879 & 455 & 812 & 1522 & 822 & 2097 & 701 \\
\hline Fluo $\alpha$ (UA) & 2019 & 442 & 741 & 1262 & 712 & 2041 & 730 \\
\hline Fluo $\beta$ (UA) & 1926 & 440 & 742 & 1371 & 761 & 2018 & 657 \\
\hline Fluo $\delta$ (UA) & 4949 & 1080 & 665 & 1348 & 678 & 1685 & 622 \\
\hline Fluo $\gamma($ UA) & 4194 & 907 & 354 & 1077 & 448 & 590 & 231 \\
\hline HIX & 1.0 & 1.2 & 3.4 & 3.2 & 3.6 & 5.0 & 6.4 \\
\hline BIX & 0.85 & 0.90 & 0.97 & 0.96 & 0.99 & 0.95 & 0.96 \\
\hline SEC Seine Cenf & & & & & & \\
\hline
\end{tabular}

SEC = Seine Centre WWTP; SAM = Seine Amont WWTP; SAV = Seine Aval; SEM = Seine Morée.

$\mathrm{BF}=$ biofiltration; $\mathrm{CAS}=$ conventional activated sludge; $\mathrm{MBR}=$ membrane bioreactor: $\mathrm{C}=$ carbon removal; $\mathrm{N}=$ nitrogen removal (nitrification + denitrification).

DOC $=$ dissolved organic carbon, UV-254 = UV absorbance at $254 \mathrm{~nm}$, Fluo $=$ fluorophore, HIX = humification index, BIX = biological activity index.

\subsection{Influence of the residual methanol concentration in the WWTP discharges}

A residual methanol concentration is present in both SEC and SAV discharges because of the post-denitrification stage. Indeed, denitrifying microorganisms needs a carbon source and when the denitrification is performed after the carbon removal and the nitrification, as in both SEC and SAV, the carbon content is too low (Rocher et al. 2012). Methanol is 
then added during this stage as carbon source, but its consumption by the microorganisms is not complete. Operationally speaking, it is interesting to study the impact of this residual concentration on the micropollutant adsorption by activated carbon. Thus, the performances obtained with the SEC discharges have been compared to performances obtained with the same water spiked with methanol $(6$ and $12 \mathrm{mgC} / \mathrm{L})$. The adsorbability of methanol has also been studied and preliminary tests demonstrated that no adsorption of methanol occurs when contacting $12 \mathrm{mgC} / \mathrm{L}$ of methanol in ultrapure water with $10 \mathrm{mgPAC} / \mathrm{L}$.

3.5. Influence of the ferric chloride

The CarboPlus ${ }^{\circledR}$ process operating in PAC configuration requires the injection of $\mathrm{FeCl}_{3}$ to stabilize the PAC bed and prevent any leakage. This substance is known to destabilize particles by neutralization of the surface charges, which could impact the adsorption of micropollutants. To evaluate the impact of $\mathrm{FeCl}_{3}, 1 \mathrm{~L}$ of SEC discharges have been contacted with $\mathrm{PAC}$ alone $(10 \mathrm{mg} / \mathrm{L}), \mathrm{FeCl}_{3}$ alone $\left(2.5 \mathrm{gFeCl}_{3} / \mathrm{m}^{3}\right)$ and both $\mathrm{PAC}$ and $\mathrm{FeCl}_{3}$ under strong mixing during $45 \mathrm{~min}$.

\section{RESULTS AND DISCUSSION}

1. Influence of PAC characteristics on its efficiency

Structural and morphological properties of the 4 tested PACs are given in the Table 2 . The removals of the micropollutants with a PAC dose of $10 \mathrm{mg} / \mathrm{L}$ during $45 \mathrm{~min}$ are also provided.

Table 2 - Characterization and performances of the 4 PACs studied

\begin{tabular}{|c|c|c|c|c|}
\hline & PB 170® & WP 235® & W 35® & PC 1000® \\
\hline Producer & DaCarb & Chemviron & Norit & DaCarb \\
\hline Raw material & Wood & Coal & Peat & Coconut \\
\hline $\begin{array}{l}\text { Bulk density } \\
\left(\mathrm{g} / \mathrm{cm}^{3}\right)\end{array}$ & 0.30 & 0.38 & 0.33 & 0.54 \\
\hline $\begin{array}{l}\text { Specific BET } \\
\text { surface }\left(\mathrm{m}^{2} / \mathrm{g}\right)\end{array}$ & $957 \pm 28$ & $909 \pm 30$ & $768 \pm 19$ & $458 \pm 14$ \\
\hline $\begin{array}{c}\text { Pore size } \\
\text { distribution } \\
\text { (micro, meso, } \\
\text { macroporous) }\end{array}$ & $\begin{array}{c}54 \%-35 \%- \\
11 \%\end{array}$ & $53 \%-31 \%-16 \%$ & $45 \%-45 \%-10 \%$ & $59 \%-29 \%-12 \%$ \\
\hline $\begin{array}{c}\text { Pore volume } \\
\text { (micro + meso) } \\
(\mathrm{mL} / \mathrm{g})\end{array}$ & 0.5066 & 0.4841 & 0.4876 & 0.2435 \\
\hline $\begin{array}{c}\text { Particle size } \\
\text { distribution } \\
(\mu \mathrm{m})\end{array}$ & $3.4-16.2-58.9$ & $3.4-18.0-58.0$ & $3.2-19.4-86.2$ & $3.7-31.7-129.4$ \\
\hline
\end{tabular}




\begin{tabular}{|c|c|c|c|c|}
\hline $\mathrm{d} 10-\mathrm{d} 50-\mathrm{d} 90$ & & & \\
\hline & \multicolumn{2}{|c|}{ Micropollutant removal (\%) - (10 mg/L of PAC, 45 min of contact) } \\
\hline $\begin{array}{c}16 \text { micro- } \\
\text { pollutants }\end{array}$ & $61 \%$ & $53 \%$ & $51 \%$ & $32 \%$ \\
\hline Atenolol & $54 \%$ & $44 \%$ & $41 \%$ & $21 \%$ \\
\hline Carbamazepine & $63 \%$ & $44 \%$ & $48 \%$ & $16 \%$ \\
\hline Ciprofloxacin & $77 \%$ & $63 \%$ & $62 \%$ & $49 \%$ \\
\hline Diclofenac & $32 \%$ & $22 \%$ & $28 \%$ & $5 \%$ \\
\hline Diuron & $75 \%$ & $66 \%$ & $60 \%$ & $24 \%$ \\
\hline Norfloxacin & $79 \%$ & $69 \%$ & $62 \%$ & $58 \%$ \\
\hline Ofloxacin & $79 \%$ & $71 \%$ & $68 \%$ & $46 \%$ \\
\hline Propranolol & $81 \%$ & $76 \%$ & $70 \%$ & $46 \%$ \\
\hline Roxithromycin & $43 \%$ & $38 \%$ & $40 \%$ & $21 \%$ \\
\hline Trimethoprim & $46 \%$ & $36 \%$ & $33 \%$ & $10 \%$ \\
\hline Dimin
\end{tabular}

1 Distribution of surface. Micropore $=<2 \mathrm{~nm}$, mesopores $=<50 \mathrm{~nm}$ and macropores $=>50 \mathrm{~nm}$.

2 Sum of 16 pharmaceuticals $=$ atenolol, bezafibrate, carbamaepine, ciprofloxacin, diclofenac, erythromycin, ketoprofen, lorazepam, metronidazole, naproxen, norfloxacin, ofloxacin, propranolol, roxithromycin, sulfamethoxazole and trimethoprim.

Among the 4 PACs, the PB 170® and WP 235® have a similar mesoporous structure with close pore size distribution and specific BET surface (900-1000 m²/g), while W 35® and especially PC 1000® have different pore surface distributions and lower specific BET surfaces (supporting material - Figure S3; Table 2). W 35® is strongly mesoporous with $45 \%$ of the BET surface resulting from mesopores, while PC $1000 ®$ is microporous with $59 \%$ of the surface resulting from micropores. 3 of the tested PACs have similar bulk densities $\left(0.30-0.40 \mathrm{~g} / \mathrm{cm}^{3}\right)$ while PC $1000 \AA$ is heavier $\left(0.54 \mathrm{~g} / \mathrm{cm}^{3}\right)$. Regarding the particle size distribution, PB $170 ®$ and WP $235 \AA$ are comparable while the two other PACs have a larger particle size distribution and a higher median diameter. This is particularly notable for the PC $1000 \AA$ which is characterized by median and d90 values twice higher than those of the PB $170 \AA$ and WP $235 \AA$.

Even if only 1 punctual experiment was performed, a clear trend can be observed with most of the compounds. For individual compounds, the PB $170 \circledR$ allows the highest removals for 15 of the 18 micropollutants and the PC $1000 \AA$ is always the worst efficient. The WP $235 \AA$ and W $35 \circledR$ seem to have similar performances, slightly weaker than PB $170 \circledR$. Overall, the sum of the 16 pharmaceuticals is removed by $61 \%, 53 \%, 51 \%$ and $32 \%$ respectively by the PB $170 ®$, WP The micropollutant removal is well correlated with the specific BET surface (Figure 1): the higher the specific BET surface, the higher the micropollutant removal. In addition, the specific BET surface is also correlated to the bulk density of the PAC, a low bulk density corresponding to a high BET surface. This relationship has been verified with 7 other PACs differing by their nature, as the bulk density is very easy to measure and could therefore be a proxy of the BET surface. Considering the 11 PAC, this link is still observed (Figure 1). Thus, the bulk density could be used as an 
237 indicator to select activated carbons and estimate their BET surface and efficiency for micropollutants removal from

238 wastewater.

240 The link between the efficiency of activated carbons and their specific BET surface $\left(600-1500 \mathrm{~m}^{2} / \mathrm{g}\right)$ has already been 241 observed in the literature (Çeçen \& Aktas 2012), but the distribution of this surface between the different categories of 242 pores (micro $<2 \mathrm{~nm}$, meso $2-50 \mathrm{~nm}$ and macropores $>50 \mathrm{~nm}$ ) has also to be considered. This is particularly important 243 in presence of organic matter because it competes with micropollutants for adsorption, directly or by pore blocking 244 (Newcombe et al. 2002; Yu et al. 2008). Thus, a mesoporous structure with a large pore size distribution should limit 245 the competition with the DOM (Ebie et al. 2001).

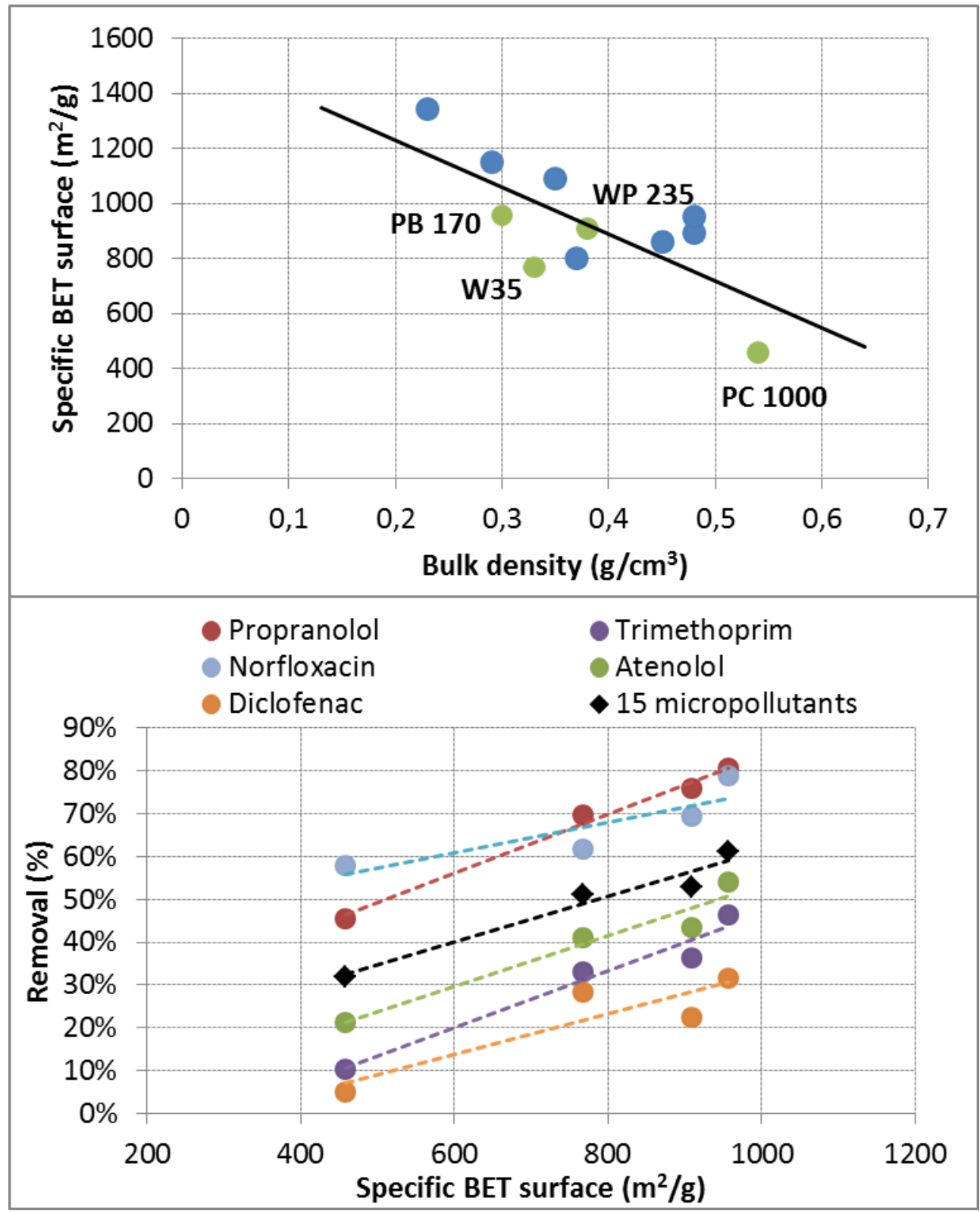


Figure 1 - Correlations between the specific BET surface and the micropollutant removals obtained with a PAC, and link with its bulk density

2. Adsorption of micropollutants on PAC

2.1. Influence of fresh PAC dose and adsorption kinetic

The Figure 2 displays the influence of the contact time and the PAC dose on the removal of micropollutants from Seine Centre discharges by PAC.

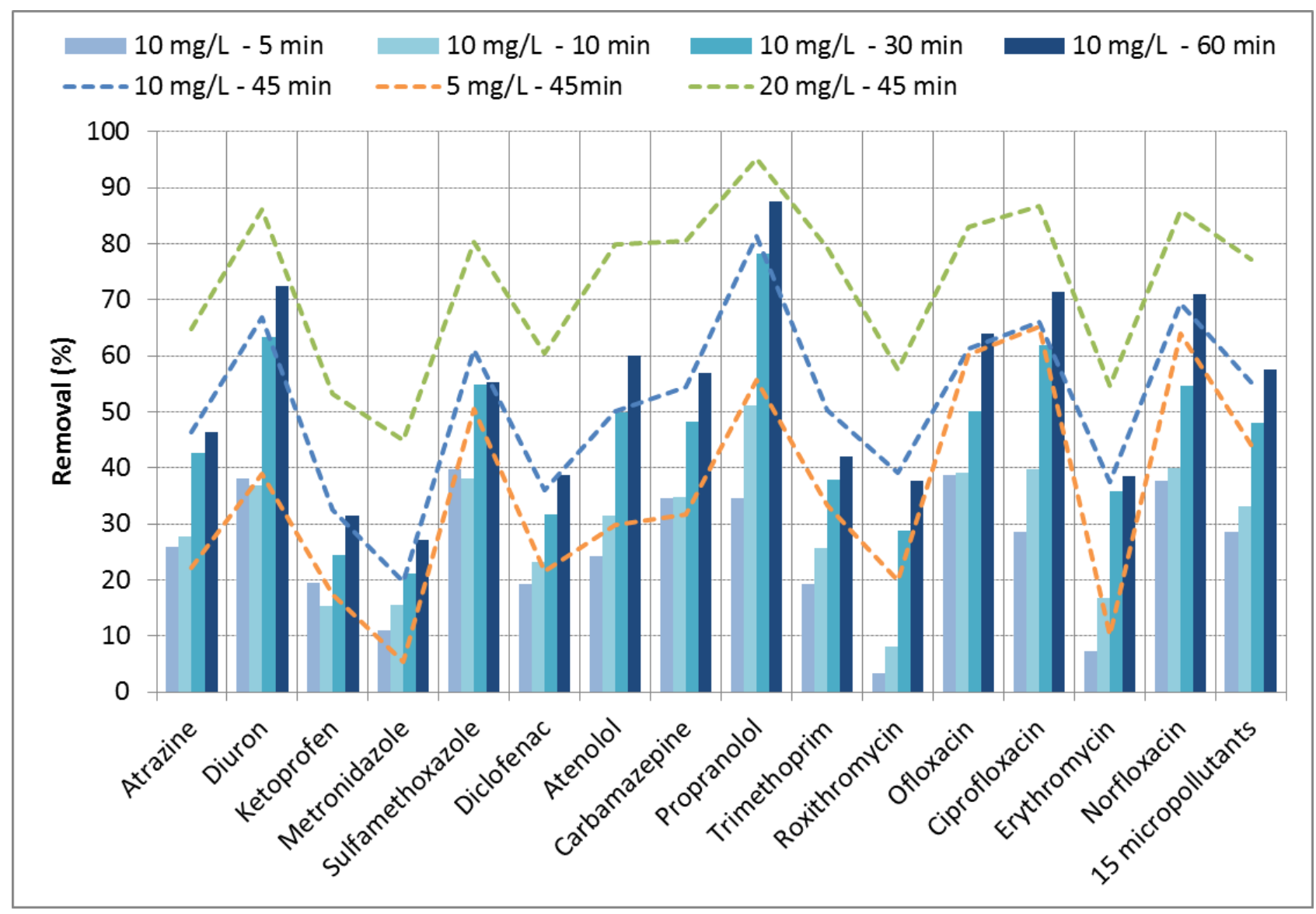

Figure 2 - Micropollutants adsorption kinetic in the Seine Centre discharges and influence of the dose on removals

According to the results (Figure 2), a higher dose of PAC logically results in higher micropollutant removals, i.e. carbamazepine (32-54-80\%; removals at 5-10-20 mgPAC/L), diclofenac (22-36-60\%), propranolol (56-81-95\%) or sulfamethoxazole (51-61-80\%). However, the relationship is not linear as doubling the PAC mass doesn't result in a doubling of the removals. Actually, the relationship is logarithmic resulting in the reaching of a plateau when increasing 
the dose, as displayed in supporting material - Figure S4. Thus, the PAC dose in wastewater has a great influence on the removal, as already observed in the literature (Snyder et al. 2007; Boehler et al. 2012; Margot et al. 2013) or at large scale with the CarboPlus ${ }^{\circledR}$ pilot (Mailler et al. 2015).Considering the individual results of the micropollutants, this positive influence of the dose is statistically significant (test of Shapiro-Wilk, Fischer and Student - p-value $<0.05$ ) between 5 and $10 \mathrm{mgPAC} / \mathrm{L}(\mathrm{p}$-value $=0.016)$ and between 10 and $20 \mathrm{mgPAC} / \mathrm{L}(\mathrm{p}$-value $=0.0005)$.

Furthermore, the removals notably increase with the contact time (Figure 2), i.e. ciprofloxacin (29-40-62-66-71\%; removals at 5-10-30-45-60 min contact times) or diclofenac (19-23-32-36-39\%). However, the PAC is very fine $(<50$ $\mu \mathrm{m})$, resulting in a relatively fast adsorption kinetic. As a consequence, although the equilibrium is not reached after 60 min, differences of removal between 30, 45 and 60 min contact time for a same PAC dose are limited $(<10 \%)$ indicating the proximity of the equilibrium. Thus, the short contact times (30-60 min) employed in PAC tertiary treatments are suitable for an efficient adsorption of micropollutants. For several compounds (8/15), such as atrazine (26-46\%; removals after 5 and $60 \mathrm{~min}$ ), norfloxacin (38-71\%), ofloxacin (39-64\%) or sulfamethoxazole (40-55\%), the removal achieved after 5 min represents more than half of the removal after $60 \mathrm{~min}$, confirming the very fast kinetic. In contrary, erythromycin (7-39\%) or roxithromycin (3-38\%) seem to have slower kinetics, probably because of their high molecular weight. These compounds will then be more sensitive to changes of contact time in adsorption processes.

\subsection{Influence of the matrix}

\subsubsection{Dissolved organic carbon}

The Figure 3 displays the removals of micropollutants observed with different types of wastewater, sorted from the highest to the lowest DOC value. 


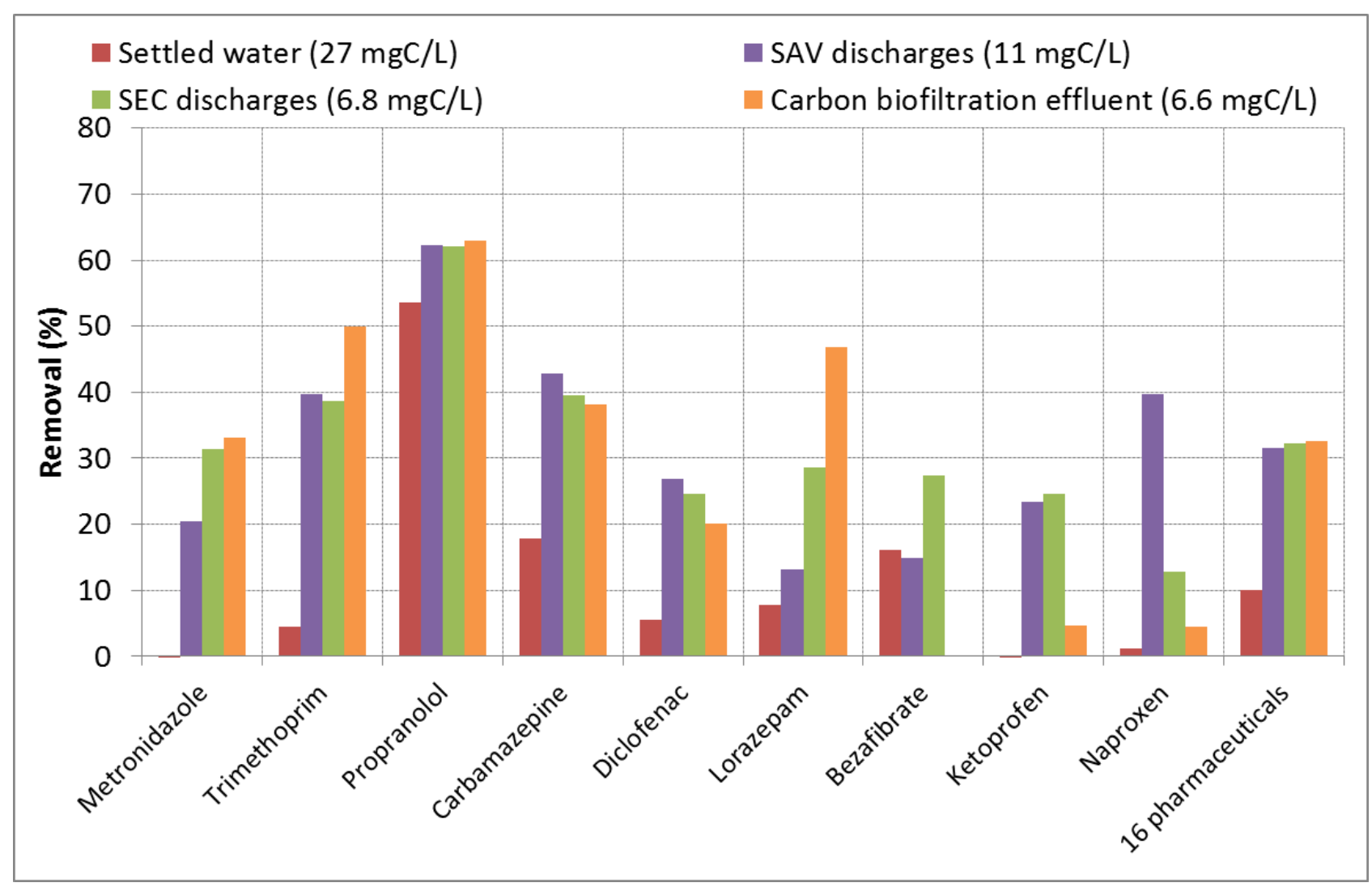

Figure 3 - Pharmaceuticals removals by PAC adsorption from different types of wastewater

Removals observed with the SEC settled water are overall lower than those from the three other wastewaters. In particular, they are significantly lower $(\mathrm{p}$-value $=0.001)$ than in the SEC discharges (water from the same WWTP), considering all the compounds displayed on Figure 3. Comparable removals are overall achieved with the 3 other waters, which have undergone an intense biological carbon treatment. For instance, the carbamazepine is removed at $18 \%$ in SEC settled water, against 38 to $42 \%$ in the other matrixes. Similarly, the trimethoprim removal increases from $5 \%$ in settled water to $39-50 \%$ in the other waters.

These results indicate that DOC value has a negative impact on micropollutant adsorption, as the removals observed in the SEC settled water, featuring the highest DOC concentration $(27 \mathrm{mgC} / \mathrm{L})$, are the lowest compare to the other waters. The negative influence of DOC on micropollutant adsorption from wastewater was also observed in the literature (de Ridder et al. 2011; Margot et al. 2013; Altmann et al. 2014). In contrary, DOC value seems to have a limited impact on propranolol behavior, a compound which is easily adsorbed by activated carbon as positively charged (Mailler et al. 2015).

According to what is previously stated, micropollutant removals should be lower in SAV discharges compared to those 
309 in the SEC carbon biofiltration effluent and discharges, regarding the differences of DOC (11 vs. 6.6-6.8 mgC/L). This is 310 observed for bezafibrate, lorazepam and metronidazole. However, removals are similar for the other compounds, in spite 311 of slightly higher influent concentrations in the SAV discharges. Besides, considering the individual removals of 312 compounds from Figure 3, the removals from SEC and SAV discharges are significantly similar $(\mathrm{p}$-value $=0.175)$. The 313 organic matter of SAV discharges should then be less competitive than organic matter from other discharges, what 314 counterbalances the higher DOC.

315 This result indicates that the sole DOC level isn't sufficient to explain the variations of removals from water to water, the 316 organic matter composition and nature have also to be considered. Considering that, the DOM nature and adsorption was 317 assessed before and after contact with PAC for these 4 waters, as well as 3 additional wastewater matrixes.

\subsubsection{Composition and adsorption of the organic matter}

Figure 4 displays the composition (indexes from 3D fluorescence analysis) of the organic matter from 7 wastewater matrixes, as well as the organic matter removal by PAC adsorption (10 mgPAC/L - $45 \mathrm{~min})$. 


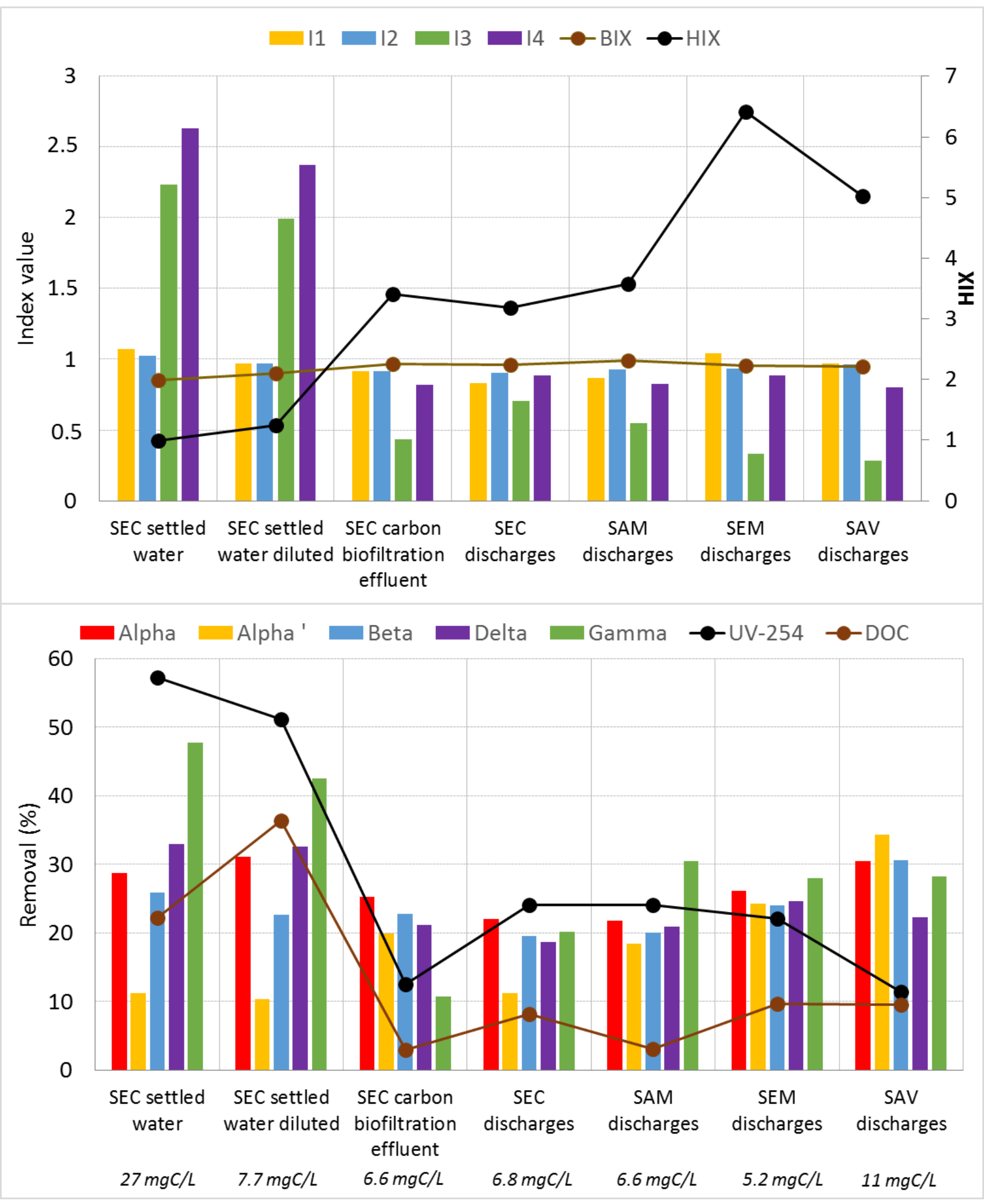

Figure 4 - DOM adsorption and distribution using the defined indexes for the different studied wastewaters

First of all, the 4 WWTP discharges (SEC, SAM, SEM and SAV) and the SEC carbon biofiltration effluent have a similar distribution of DOM with a large fraction of humic-like organic matter (peaks $\alpha, \alpha^{\prime}$ and $\beta$; indexes I1 and I2), and a smaller fraction of organic matter resulting from bacterial activity ( $\gamma$ and $\delta$; I3 and I4), as shown on Figure 4 and in Table 
1. In contrary, the DOM distribution is different in the SEC settled water with very high I3 and I4 indexes, characterizing protein molecules, compared to I1 and I2 indexes, characterizing the humic-like substances. This indicates that carbon biological treatments significantly remove DOC and fluorophores $\delta$ and $\gamma$ (see SEC settled water and carbon biofiltration effluent in Table 1), resulting in a significant modification of the DOM distribution (Figure 4). Together with this difference of DOM composition, the SEC settled water has higher DOC (27 mgC/L) and UV-254 $\left(0.859 \mathrm{~cm}^{-1}\right)$ values, highlighting a higher quantity of DOM.

In addition, the HIX increases along the different steps of wastewater treatment, as shown by the low HIX in the SEC settled water (1.0) and the higher HIX after the biological treatments (> 3). This suggests that small protein molecules $(\delta$ and $\gamma)$ are transformed into humic-like substances $\left(\alpha, \alpha^{\prime}\right.$ and $\left.\beta\right)$ during biological treatments, explaining the HIX increase. The HIX from SAM and SEC discharges, as well as SEC carbon biofiltration effluent, are similar (3.2-3.6), while those from SAV and SEM discharges are higher (5.0-6.4), resulting from higher hydraulic retention times.

Regarding the removal of DOM by activated carbon, DOC and UV-254 removals are notably higher in the SEC settled water compared to the other ones. This is consistent as DOC and UV-254 are much higher in this water. This suggests that in this water, less sites will be available for micropollutants as more DOM is sorbed, what is consistent with micropollutants results (Figure 3). For the other wastewaters, the DOM removal is rather comparable (10-25\% for DOC and $5-10 \%$ for UV-254).

In addition, fluorophores removals are rather similar in all wastewaters except in the SEC settled water. In the WWTP discharges, all the fluorophores are removed between 10 and 30\%. In contrary, in SEC settled water, fluorophores $\delta$ and $\gamma$ are predominant (I3 and I4) and are better removed (35-50\%) than the other fluorophores. They are also better removed than in the other water. In consequence, these fluorophores will have the highest impact on the competition with micropollutants for adsorption. This is consistent with the study of (de Ridder et al. 2011) which identified the small size DOM as the most competing ones for adsorption. Moreover, the fluorophores removal pattern is the same in SEC diluted settled water, confirming that the distribution of DOM is as important in the adsorption process as the DOC value.

In this context, and considering that the carbon biological treatment significantly reduces the DOC and the quantity of fluorophores $\delta$ and $\gamma$ (the most competing DOM), the lower removals of micropollutants by PAC in the SEC settled water compared to the other waters are then consistent. Indeed, the competition is stronger in this water resulting from i) a higher quantity of DOM (DOC and UV-254) and ii) a different DOM distribution, with more small protein-like substances and less humic-like substances. In addition, I3 and I4 are lower in the SAV discharges than in SEC carbon biofiltration 
effluent and discharges, together with a higher HIX. This means that this water has less very competitive DOM what counterbalances the higher DOC, resulting in similar micropollutants removals.

It can be concluded that, besides a low DOC, low I3 and I4 indexes, together with a high HIX, are positive for the minimization of DOM competition during the micropollutants adsorption.

\subsubsection{Presence and concentration of methanol}

The micropollutant and organic matter removals obtained in presence of a residual concentration of methanol are presented in Figure 5.

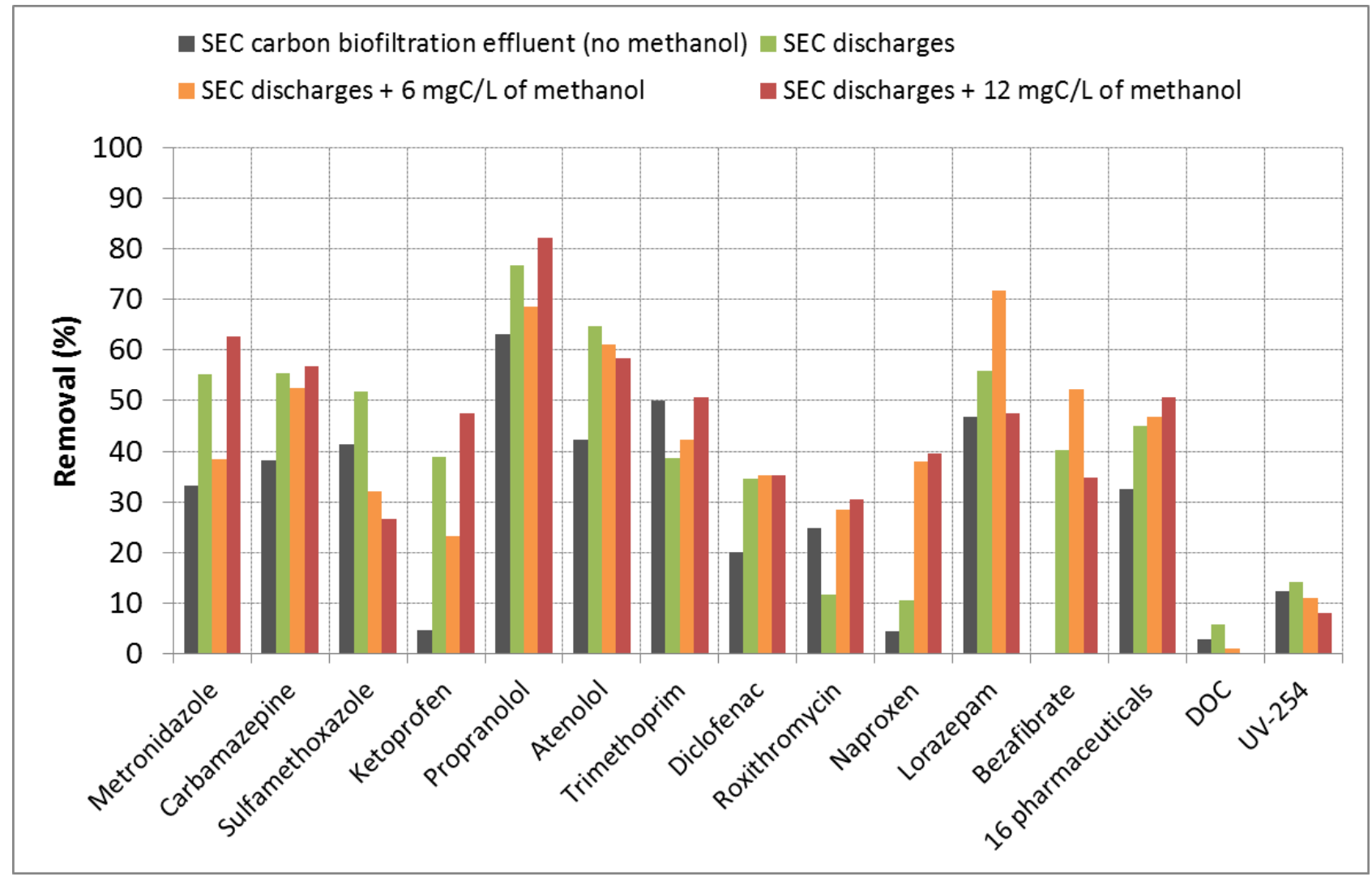

Figure 5 - Impact of a residual concentration of methanol in the WWTP discharges on the adsorption of pharmaceuticals by PAC

The comparison of removals obtained in the carbon biofiltration effluent and in the SEC discharges allows assessing the impact of the methanol presence in the wastewater on the PAC adsorption (Figure 5). Its presence doesn't decrease the performances as the removals observed in the SEC discharges are similar or higher than those in the carbon biofiltration 
effluent. The better removals in the SEC discharges could be explained i) by the methanol itself, and ii) by the carbon and nitrogen treatment achieved in the second and third biofiltration stages. but further experiments are needed to bring an answer.

Moreover, no clear trend is observed between the increase of the residual concentration of methanol and the micropollutant removals, except for sulfamethoxazole and naproxen for which the removal decrease and increase respectively. However, the results indicate that the increase of the methanol concentration doesn't lead to a significant degradation of the PAC performances for most compounds.

Thus, results have shown that the residual concentration of methanol doesn't affect negatively the removal of micropollutants by activated carbon (Figure 5). In contrary, its presence in biological treatment effluents could favor a biological activity in the tertiary treatments by activated carbon.

2.2. Influence of the injection of $\mathrm{FeCl}_{3}$

The ferric chloride influence on the fate of micropollutants in presence of PAC is illustrated on figure 7.

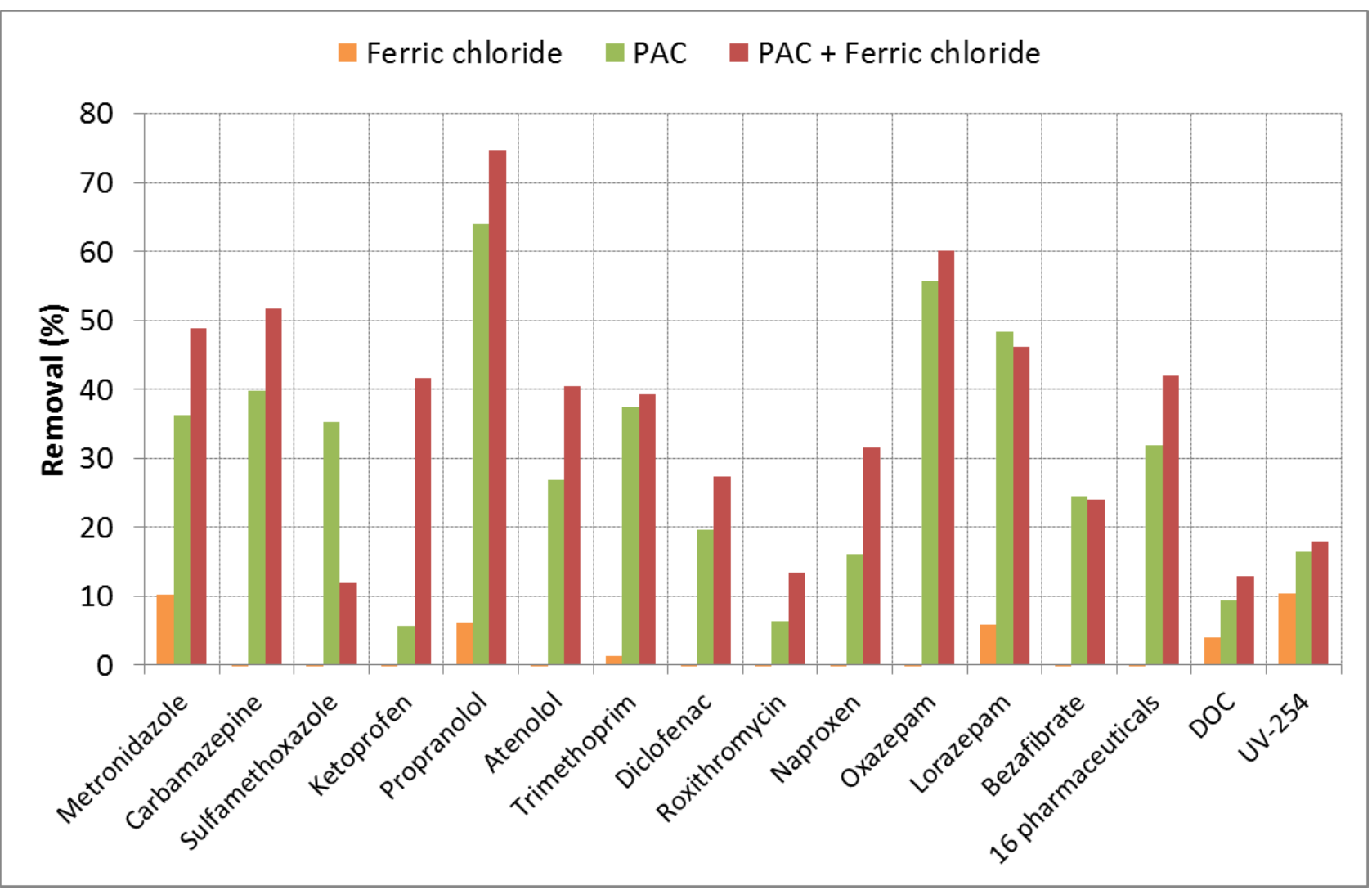




\section{Figure 6 - Influence of the presence of $\mathrm{FeCl}_{3}$ on the pharmaceuticals removals by $\mathrm{PAC}$ adsorption}

Three types of behaviors are observed for micropollutants. For most compounds, such as carbamazepine, beta blockers or diclofenac, and for DOM (DOC and UV-254), a slightly higher removal (+ 5-15\%) is obtained by coupling PAC and ferric chloride, probably by coagulation of the colloidal fraction. These differences are not significant taking uncertainties into account, but 10 compounds in 13 , as well as DOC and UV-254, have a greater removal in presence of $\mathrm{FeCl}_{3}$. In contrary, no clear influence is observed for lorazepam and bezafibrate. Finally, sulfamethoxazole seems to be the only one with a lower removal (- 30\%) in presence of ferric chloride.

(Margot et al. 2013) also observed a positive effect of the coagulant on micropollutant removals. However, the mechanism at the origin of this improvement is not identified. Supplementary tests are required to determine if coagulation, complexation or direct decrease of the competition with organic matter are involved.

\section{CONCLUSIONS}

The Parisian public sanitation service (SIAAP) and the Water Environment and Urban Systems laboratory (LEESU) study the CarboPlus ${ }^{\circledR}$ process at large scale, in collaboration with the SAUR teams. In parallel to the study of the large scale pilot, complementary laboratory scale experiments were carried out to improve the understanding of the micropollutants adsorption on activated carbon, in particular PAC.

These experiments allowed displaying the links between structural properties of activated carbons and their efficiency to remove micropollutants. In particular, it has been shown that the PAC performances are closely related to the specific BET surface, which can easily be estimated through the bulk density measure.

The strong influence of the PAC dose has also been confirmed, as well as the suitability of the adsorption kinetic (less than one hour) for WWTP application (operational requirements). In an operational point of view, the injection of $\mathrm{FeCl}_{3}$ doesn't disrupt the adsorption process. A slight improvement is even observed for most compounds $(+10-15 \%)$, except for sulfamethoxazole, probably through coagulation of the colloidal fraction of the DOM. In contrary, the residual concentration of methanol present in the WWTP discharges due to the post denitrification process seems to have no impact on the fate of most pharmaceuticals. 
426 Then, this study highlighted the differences of micropollutants adsorption in the various wastewater matrixes. The DOC

427 concentration is important considering the competition of adsorption but it isn't always sufficient to explain the 428 performances reductions from water to water. It has been shown that the distribution of the different molecular 429 components of the DOM should be considered in addition to the quantity of DOM. Indeed, small protein-like fluorophores 430 have been identified as the most problematic for adsorption competition in wastewater, while a high HIX, highlighting 431 the humification of the DOM, is favorable to micropollutants adsorption. The reduction of protein-like substances in 432 wastewater is then a way to maximize the adsorption of micropollutants by activated carbon.

\section{ACKNOWLEDGEMENT}

This study has been performed within the framework of the OPUR research program. The authors would like to thank 438 Benjamin Cassier and Mélanie Gobin, as well as the SIAAP (Céline Briand), the SAUR (Séverine Bareilles), the ISA 439 (Antoine Vauchez, Mikaël Tournier, Florent Lafay and Loic Spinner), the LEESU and UTC teams for their technical 440 support and their active participation to the sampling campaigns and analyses. 


\section{REFERENCES}

Abegglen C. and Siegrist H. (2012). Micropolluants dans les eaux résiduaires urbaines. Etapes de traitement supplémentaire dans les stations d'épuration. (in French).

Altmann J., Ruhl A. S., Zietzschmann F. and Jekel M. (2014). Direct comparison of ozonation and adsorption onto powdered activated carbon for micropollutant removal in advanced wastewater treatment. Water Research $55(0), 185-93$.

Baudu M., Guibaud G., Raveau D. and Lafrance P. (2001). Prediction of Adsorption from Aqueous Phase of Organic Molecules as a Function of Some Physicochemical Characteristics of Activated Carbons. Water Quality Research 36(4), 631-57.

Boehler M., Zwickenpflug B., Hollender J., Ternes T., Joss A. and Siegrist H. (2012). Removal of micropollutants in municipal wastewater treatment plants by powder-activated carbon. International Water Association, London, Royaume-Uni.

Çeçen F. and Aktas Ö. (2012). Activated carbon for water and wastewater treatment integration of adsorption and biological treatment. Wiley-VCH, Weinheim, Germany.

de Ridder D. J., Verliefde A. R., Heijman S. G., Verberk J. Q., Rietveld L. C., van der Aa L. T., Amy G. L. and van Dijk J. C. (2011). Influence of natural organic matter on equilibrium adsorption of neutral and charged pharmaceuticals onto activated carbon. Water Sci Technol 63(3), 416-23.

de Ridder D. J., Villacorte L., Verliefde A. R. D., Verberk J. Q. J. C., Heijman S. G. J., Amy G. L. and van Dijk J. C. (2010). Modeling equilibrium adsorption of organic micropollutants onto activated carbon. Water Research $4 \mathbf{4}(10), 3077-86$.

Delgado L. F., Charles P., Glucina K. and Morlay C. (2012). The removal of endocrine disrupting compounds, pharmaceutically activated compounds and cyanobacterial toxins during drinking water preparation using activated carbon-A review. Science of the Total Environment 435-436(0), 509-25.

Ebie K., Li F., Azuma Y., Yuasa A. and Hagishita T. (2001). Pore distribution effect of activated carbon in adsorbing organic micropollutants from natural water. Water Research $35(1), 167-79$.

Hudson N., Baker A. and Reynolds D. (2007). Fluorescence analysis of dissolved organic matter in natural, waste and polluted waters-a review. River Research and Applications 23(6), 631-49.

Li L., Quinlivan P. A. and Knappe D. R. U. (2002). Effects of activated carbon surface chemistry and pore structure on the adsorption of organic contaminants from aqueous solution. Carbon 40(12), 2085-100.

Loos R., Carvalho R., António D. C., Comero S., Locoro G., Tavazzi S., Paracchini B., Ghiani M., Lettieri T., Blaha L., Jarosova B., Voorspoels S., Servaes K., Haglund P., Fick J., Lindberg R. H., Schwesig D. and Gawlik B. M. (2013). EU-wide monitoring survey on emerging polar organic contaminants in wastewater treatment plant effluents. Water Research $47(17), 6475-87$.

Mailler R., Gasperi J., Coquet Y., Deshayes S., Zedek S., Cren-Olivé C., Cartiser N., Eudes V., Bressy A., Caupos E., Moilleron R., Chebbo G. and Rocher V. (2014a). Study of a large scale powdered activated carbon pilot: Removals of a wide range of emerging and priority micropollutants from wastewater treatment plant effluents. Water Research(0).

Mailler R., Gasperi J., Coquet Y., Deshayes S., Zedek S., Cren-Olivé C., Cartiser N., Eudes V., Bressy A., Caupos E., Moilleron R., Chebbo G. and Rocher V. (2015). Study of a large scale powdered activated carbon pilot: Removals of a wide range of emerging and priority micropollutants from wastewater treatment plant effluents. Water Research 72(0), 315-30.

Mailler R., Gasperi J., Rocher V., Gilbert-Pawlik S., Geara-Matta D., Moilleron R. and Chebbo G. (2014b). Biofiltration vs conventional activated sludge plants: what about priority and emerging pollutants removal? Environmental Science and Pollution Research 21(8), 5379-90.

Margot J., Kienle C., Magnet A., Weil M., Rossi L., de Alencastro L. F., Abegglen C., Thonney D., Chèvre N., Schärer M. and Barry D. A. (2013). Treatment of micropollutants in municipal wastewater: Ozone or powdered activated carbon? Science of the Total Environment 461-462(0), 480-98.

Matsui Y., Fukuda Y., Inoue T. and Matsushita T. (2003). Effect of natural organic matter on powdered activated carbon adsorption of trace contaminants: characteristics and mechanism of competitive adsorption. Water Research $37(18), 4413-24$. 
Miège C., Choubert J. M., Ribeiro L., Eusèbe M. and Coquery M. (2009). Fate of pharmaceuticals and personal care products in wastewater treatment plants - Conception of a database and first results. Environmental Pollution $157(5), 1721-6$.

Newcombe G., Morrison J., Hepplewhite C. and Knappe D. R. U. (2002). Simultaneous adsorption of MIB and NOM onto activated carbon: II. Competitive effects. Carbon 40(12), 2147-56.

Parlanti E., Morin B. and Vacher L. (2002). Combined 3D-spectrofluorometry, high performance liquid chromatography and capillary electrophoresis for the characterization of dissolved organic matter in natural waters. Organic Geochemistry $33(3), 221-36$.

Rocher V., Paffoni C., Goncalves A., Guerin S., Azimi S., Gasperi J., Moilleron R. and Pauss A. (2012). Municipal wastewater treatment by biofiltration: comparisons of various treatment layouts. Part 1: assessment of carbon and nitrogen removal. Water Science and Technology 65(9), 1705-12.

Ruel S. M., Choubert J. M., Budzinski H., Miege C., Esperanza M. and Coquery M. (2012). Occurrence and fate of relevant substances in wastewater treatment plants regarding Water Framework Directive and future legislations. Water Science and Technology 65(7), 1179-89.

Snyder S. A., Adham S., Redding A. M., Cannon F. S., DeCarolis J., Oppenheimer J., Wert E. C. and Yoon Y. (2007). Role of membranes and activated carbon in the removal of endocrine disruptors and pharmaceuticals. Desalination $202(1-3), 156-81$.

Ternes T. A., Meisenheimer M., McDowell D., Sacher F., Brauch H.-J., Haist-Gulde B., Preuss G., Wilme U. and Zulei-Seibert N. (2002). Removal of Pharmaceuticals during Drinking Water Treatment. Environmental Science \& Technology 36(17), 3855-63.

Verlicchi P., Al Aukidy M. and Zambello E. (2012). Occurrence of pharmaceutical compounds in urban wastewater: Removal, mass load and environmental risk after a secondary treatment-A review. Science of the Total Environment $429(0), 123-55$.

Yu Z., Peldszus S. and Huck P. M. (2008). Adsorption characteristics of selected pharmaceuticals and an endocrine disrupting compound-Naproxen, carbamazepine and nonylphenol—on activated carbon. Water Research 42 (12), 2873-82.

Zietzschmann F., Altmann J., Ruhl A. S., Dünnbier U., Dommisch I., Sperlich A., Meinel F. and Jekel M. (2014). Estimating organic micro-pollutant removal potential of activated carbons using UV absorption and carbon characteristics. Water Research 56(0), 48-55.

Zsolnay A., Baigar E., Jimenez M., Steinweg B. and Saccomandi F. (1999). Differentiating with fluorescence spectroscopy the sources of dissolved organic matter in soils subjected to drying. Chemosphere 38(1), 45-50. 